\title{
Changes in quality of nonaged pasta filata Mexican cheese during refrigerated vacuum storage
}

\author{
Lucía Fuentes, ${ }^{*}$ Javier Mateo, $\dagger^{1}$ Emiliano J. Quinto, $\ddagger$ and Irma Caroł‡ \\ *Instituto Tecnológico Superior del Oriente del Estado de Hidalgo, Carretera Apan-Tepeapulco, Km 3.5, Colonia Las Peñitas, 43900, Apan, \\ Mexico \\ †Departamento de Higiene y Tecnología de los Alimentos, Campus Vegazana s/n, 24007, León, Spain \\ ‡Departamento de Nutrición y Bromatología, Facultad de Medicina, Universidad de Valladolid, Avda. Ramón y Cajal 7, 47005, Valladolid, Spain
}

\section{ABSTRACT}

Six batches of Oaxaca cheese (a Mexican pasta filata cheese) from 3 dairy plants were sampled and vacuum-packaged at $8^{\circ} \mathrm{C}$ up to $24 \mathrm{~d}$. Counts of principal microbial groups, $\mathrm{pH}$, levels of sugars, organic acids, lipolytic and proteolytic indices, and texture, color, and meltability values of cheeses were studied at $\mathrm{d} 1,8,16$ and 24 of storage. A descriptive sensory analysis of selected taste, odor, and texture characteristics was also carried out. The main changes in the cheeses during the storage were decreases in $\mathrm{pH}$, hardness, elasticity, and whiteness, and an increase in meltability. Neither lipolytic nor proteolytic activities were evident during the storage of cheeses. Storage time resulted in a gradual quality loss of unmelted cheeses. This loss of quality might be related to the decrease of hardness and the appearance off-flavors.

Key words: Oaxaca cheese, cheese shelf life, stretched curd, traditional cheese

\section{INTRODUCTION}

Changes in the quality characteristics of several wellknown styles of pasta filata cheese during refrigerated storage; for example, low-moisture mozzarella, Italian mozzarella, (Kindstedt, 1993; Costabel et al., 2007; Kindstedt et al., 2010), have shown that storage time affects texture and melting properties of cheese. Thus, cheese quality appears to improve during the first weeks of storage and then declines due to excessive softness and fluidity when cheeses are melted. Changes in $\mathrm{pH}$, acidity, color, and the structure of para-casein fibers during storage have also been described. The abovementioned effects and changes have been mainly attributed to proteolysis, fermentation of residual carbohydrates, and calcium dissociation and protein solvation

Received March 20, 2014.

Accepted January 12, 2015.

${ }^{1}$ Corresponding author: jmato@unileon.es processes. Furthermore, it has been found that cheese milk composition and manufacturing conditions (e.g., stretching conditions, salt content) play an important role in the changes in composition and functionality of pasta filata cheeses during storage (Yun et al., 1993; Rudan et al., 1999: Kindstedt et al., 2010).

Oaxaca cheese is a nonaged pasta filata cheese very popular in Mexico, and which is widely used to prepare dishes in which it is typically melted (DomínguezLópez, et al., 2011). This semi-soft cheese is characterized by a visible fibrous texture (resembling chicken breast) and a characteristically mild flavor (VillanuevaCarvajal et al., 2012). Oaxaca cheese has been, and is still, made from raw milk in small-scale dairy plants, although when produced on a medium- and large-scale, it is usually made from pasteurized milk (DomínguezLópez et al., 2011). The making process of Oaxaca cheese involves, as key steps, mixed coagulation of milk, acidification of curd to a $\mathrm{pH}$ of approximately 5.3 , kneading and stretching of the acidified curd in hot water (approximately $80^{\circ} \mathrm{C}$ ), when long thin strips of curd are formed, salting of strips by adding dry salt, and finally cutting of strips into segments that are wound to form ball-shaped 0.25 - to $5-\mathrm{kg}$ pieces of cheese (Aguilar-Uscanga et al., 2006; Colín-Cruz et al., 2012). At present, Oaxaca cheese for retail sale is commonly vacuum-packaged to preserve its freshness for longer. Composition and processing of Oaxaca cheese (De Oca-Flores et al., 2009; Morales-Celaya et al., 2012) resemble, to some extent, those of Asadero cheese (Alba et al., 1990), another Mexican pasta filata cheese, and low-moisture mozzarella cheese (Kindstedt, 1993).

Although the effects of storage on quality of a variety of pasta filata cheeses have been well documented, the changes that occur in Oaxaca cheese during storage have not been studied. Therefore, the present study aimed to evaluate the significance of refrigerated storage on selected quality characteristics (chemical, microbiological, functional, and sensorial) of Oaxaca cheese produced following traditional methods. This research will add knowledge about the effects of refrigerated storage on pasta filata family of cheeses. 


\section{MATERIALS AND METHODS}

\section{Sampling}

Six batches of raw-milk Oaxaca cheese from 3 small plants (Valle de Tucilango de Bravo, Hidalgo, Mexico) were sampled (2 batches per plant being prepared on different days). Samples consisted of 4 vacuum-packaged cheeses per batch, each cheese weighing approximately $1 \mathrm{~kg}$. Samples were taken randomly within the first $24 \mathrm{~h}$ after production, and then transported under refrigeration to the laboratory, where samples were stored in a chamber at $8^{\circ} \mathrm{C}$ (the storage temperature used by local retailers) for up to $24 \mathrm{~d}$. A cheese from each batch was sampled from the chamber at d 1, 8, 16, and 24 of storage for further analysis.

\section{Microbial Analysis}

From each sample, just after sampling, a 10-g aliquot was obtained aseptically by means of radial cuts and homogenized in $90 \mathrm{~mL}$ of buffered peptone water (Oxoid Ltd., Basingstoke, UK) according to IDF (1995, 1996) using a Stomacher 400 circulator (Seward Ltd., London, UK) for $2 \mathrm{~min}$. Duplicate serial dilutions were prepared in buffered peptone water, and then $1 \mathrm{~mL}$ of each dilution was plated on specific media.

Counts of aerobic mesophilic bacteria were determined on plate count agar (Difco Laboratories, Detroit, MI) incubated at $32^{\circ} \mathrm{C}$ for $48 \mathrm{~h}$. Lactic acid bacteria (LAB) were enumerated on different media according to the bacterial genus to be tested and using the doublelayered agar method (Fox et al., 2000): Lactobacillus spp. on de Man, Rogosa, Sharpe agar (MRS; Oxoid) adjusted to $\mathrm{pH} 5.5$ with lactic acid; Lactococcus spp. on M17 agar (Oxoid); and Enterococcus spp. on KF Streptococcus agar (Oxoid). The MRS and M17 agar plates were incubated at both $30^{\circ} \mathrm{C}$ and $45^{\circ} \mathrm{C}$ for 48 to 72 $\mathrm{h}$ to differentiate between mesophilic and thermophilic LAB, respectively; and KF Streptococcus agar plates were incubated at $35^{\circ} \mathrm{C}$ for $48 \mathrm{~h}$. Furthermore, molds and yeasts were determined on potato dextrose agar (Oxoid Ltd.) acidified using $10 \%$ tartaric acid to $\mathrm{pH}$ 3.5 , at $22^{\circ} \mathrm{C}$ for $7 \mathrm{~d}$; and Escherichia coli and coliforms were studied on 3M Petrifilm Escherichia coli/coliform plates (3M Microbiology, St. Paul, MN) at $37^{\circ} \mathrm{C}$ for 24 to $48 \mathrm{~h}$.

\section{Chemical Analysis}

A 150-g subsample was taken from each cheese for chemical analysis. Subsamples were homogenized and stored for up to $3 \mathrm{mo}$ at $-20^{\circ} \mathrm{C}$ for further analysis.
Cheeses were analyzed for moisture (atmospheric oven method), protein (Kjeldahl method), and ash (dry ash method) in accordance to the procedures described by AOAC International (1999), and fat was analyzed using Van Gulik butyrometers (IDF, 1986). Lactic and acetic acid contents were determined using a chromatographic method (González de Llano et al., 1996). Sugars were analyzed using the same method except that the column temperature was $60^{\circ} \mathrm{C}$, detection was performed using a differential refractometer, and the eluent was 5 $\mathrm{m} M \mathrm{H}_{2} \mathrm{SO}_{4}$ at a constant flow rate of $0.6 \mathrm{~mL} / \mathrm{min}$.

For the analysis of FFA, cheese fat was extracted (Bligh and Dyer, 1959) and FFA were subsequently extracted from the fat and methylated (García-Regueiro et al., 1994). Then, FAME were identified and quantified by gas chromatography (Osorio et al., 2007). Water-soluble nitrogen (WSN) was measured by Kjeldahl procedure from an aqueous extract of cheese obtained as follows: $10 \mathrm{~g}$ of cheese was homogenized in $80 \mathrm{~mL}$ of water, and centrifuged at $750 \times g$ at $20^{\circ} \mathrm{C}$ for 15 min; afterward, the supernatant was filtered and the residue was subjected to the above-mentioned steps. Both supernatants were mixed and used for analysis. Nonprotein nitrogen in 12\% TCA was also determined by Kjeldahl procedure from $25 \mathrm{~mL}$ of the WSN extract. Moreover, $\alpha$-amino $\mathrm{N}\left(\alpha-\mathrm{NH}_{2}\right)$ was determined by the ninhydrin method (Rosen, 1957).

\section{Functional Properties}

Flowability tests were carried out in triplicate following the method described by Guinee et al. (2000); results were expressed as the percentage increase in the cheese disc diameter upon heating at $280^{\circ} \mathrm{C}$ for $4 \mathrm{~min}$. Color was measured on the surface of unmelted cheese samples at room temperature $\left(20^{\circ} \mathrm{C}\right)$ using a spectrophotometer (CR-300, Minolta, Osaka, Japan) with the D65 illuminant at $10^{\circ}$ observer angle, in SCI mode, and with 11-mm aperture of the instrument for illumination and 8-mm aperture for measurement. Color was also measured in melted cheeses under the same conditions, after a 4 -min heating $\left(280^{\circ} \mathrm{C}\right)$ followed by a 15-min cooling period. Texture profile analysis was carried out with a texture analyzer (Universal, Stable Micro Systems, Godalming, UK) fitted with a $50-\mathrm{kg}$ load cell. Four cubes of unmelted cheese $\left(2 \mathrm{~cm}^{3}\right)$ were obtained from each sample and compressed twice, at room temperature, with a 25 -mm-diameter cylindrical probe at $1 \mathrm{~mm} / \mathrm{s}$ to $50 \%$ of their original height. The characteristics determined from the force-time curves were hardness, adhesiveness, springiness, and cohesiveness (Van Vliet, 1991). 


\section{Sensory Analysis}

Descriptive sensory analysis of cheeses was carried out by 9 trained panelists following the recommendations of Poste et al. (1991). Assessors were staff and students of the Instituto de Ciencias Agropecuarias (ICAP), Universidad Autónoma del Estado de Hidalgo, Tulancingo, Mexico, who were trained in ten 30-min sessions. During training, relevant flavor and texture cheese characteristics reported by Retiveau et al. (2005) and Foegeding and Drake (2007) were explained and discussed. Furthermore, 5 Oaxaca cheeses purchased from the market were tasted. Afterward, a reduced set of characteristics was selected for use in further analysis. These were considered as most appropriate to evaluate changes in flavor and texture of Oaxaca cheeses during storage, attributable to acidification, proteolysis, lipolysis, and loss of flavor. Reference standards for those characteristics were prepared and presented to the assessors for training purposes. The proposed characteristics (reference used is given in parentheses) were as follows: acidity and bitterness ( $3 \mathrm{~g}$ of citric acid and $1 \mathrm{~g}$ of caffeine per $100 \mathrm{~g}$ of nonsalted ricotta, respectively); sour odor (milk acidified by an homofermentative culture); buttery odor (10 g of butter dispersed in $100 \mathrm{~mL}$ of milk); cheese-strength odor ( $2 \mathrm{~mL}$ of Cheddar cheese flavor in $100 \mathrm{~mL}$ of milk); and creaminess - the extent to which the texture has broken down to semi-liquid paste, assessed between tongue and palate during mastication (spreadable processed cheese). Finally, cheeses purchased for training were tasted and ranked according to the intensity of those characteristics.

The sensory analysis was carried out in 8 sessions in a tasting room at $20^{\circ} \mathrm{C}$ (3 cheeses from different plants with the same storage days were tasted by session), in individual partitioned-off booths under soft white lighting. Samples were presented into 3 small, white plastic glasses, each glass containing four $1.5-\mathrm{cm}^{3}$ cubes of cheese with toothpicks. Glasses were coded with randomly chosen 3 -digit numbers and capped with polystyrene film. A small cup of still mineral water and salt-free bread crackers were given to the assessors to cleanse their palates between samples. Assessors were asked to evaluate the selected characteristics on a 9-point linear scale, where 1 represented the absence or very low intensity of a specific descriptor, and 9 a very high intensity (referring to the reference standard). Odor was evaluated first; assessors were asked to remove the plastic film from a glass with cheese and then to quickly inhale the odor. For taste evaluation, assessors were asked to chew a cheese cube (5 chews), distribute the sample on the tongue surface, and leave it there for a while for better perception of each sample taste. Afterward, texture was evaluated by introducing a cheese into the mouth and, after 5 chews, pressing the cheese against the palate with the tongue. Finally, assessors were asked to provide an acceptability score regarding flavor and texture. A 2-point scale was used for this purpose, where 1 was acceptable and 0 was unacceptable for sale and consumption. When a cheese was scored as 0, assessors had to explain the main reasons for that low score. Assessors were allowed to swallow the samples and then to repeat the taste, texture, and acceptability evaluations with a second cube of cheese if so desired.

\section{Statistical Analysis}

A mixed-model ANOVA was used to determine significant effects of storage times (day of storage) on cheese quality characteristics. Storage time was included as a fixed factor and dairy plant as a random factor. When the fixed factor was significant $(P<0.05)$, the ANOVA was followed by the Tukey statistical test $(P<0.05)$. This test was also used to compare the means of the variables between cheeses from different dairy plants. The analyses were carried out using the Statistica package (release 6.0; Statsoft Inc., Tulsa, OK).

\section{RESULTS AND DISCUSSION}

\section{Changes in Microbial Populations of Cheeses During Storage}

Table 1 shows the microbial counts of Oaxaca cheese during the $24 \mathrm{~d}$ of storage under vacuum at $8^{\circ} \mathrm{C}$. Mesophilic lactococci maintained initial levels during storage and were the dominant LAB group. Counts of lactococci and lactobacilli were in agreement with those reported previously by Saxer et al. (2013) in Oaxaca cheese. However, counts of enterococci were higher $\left(10^{1.5} \mathrm{cfu} / \mathrm{g}\right.$ higher $)$ in the present study, which could be attributed to the fact that we analyzed raw-milk cheeses, whereas Saxer et al. (2013) studied pasteurized-milk cheeses. Regarding storage-related changes, an increase in the levels of mesophilic lactobacilli was observed from d 8 to 16 . Moreover, decreases in the levels of both thermophilic and mesophilic lactococci and enterococci were not observed until the end of the storage period. Low salt concentrations in cheese and low storage temperatures are factors contributing to slow rates of LAB death (Moller et al., 2013). As in the present study, an increase in lactobacilli counts and a constant level or decrease in lactococci counts were observed during storage of mozzarella cheese (Conte et al., 2007; Yazici et al., 2010). 
Table 1. Changes in the counts (mean \pm SD) of different microbial groups $\left(\log _{10} \mathrm{cfu} / \mathrm{g}\right)$ in Oaxaca cheese during storage under vacuum at $8^{\circ} \mathrm{C}$

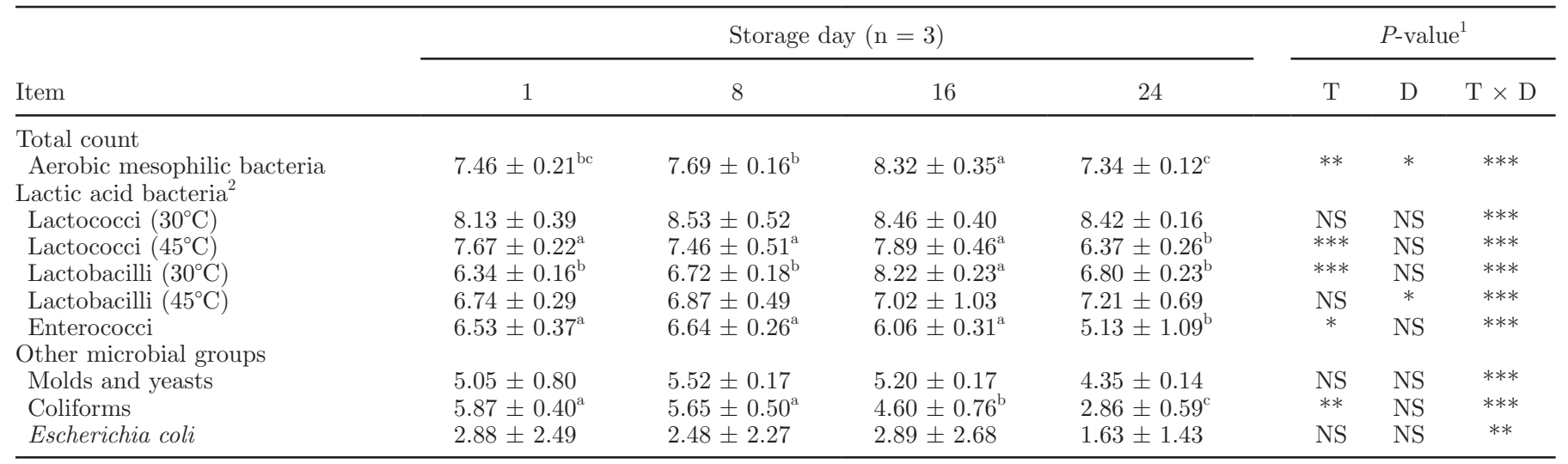

${ }^{a-c}$ Means in the same row with different superscripts were significantly different $(P<0.05)$.

${ }^{1} \mathrm{~T}=$ time (fixed factor); $\mathrm{D}=$ dairy plant (random factor); $\mathrm{T} \times \mathrm{D}=$ time $\times$ dairy plant interaction (random factor).

${ }^{2}$ The de Man, Rogosa, and Sharpe and M17 agar plates were incubated at both $30^{\circ} \mathrm{C}$ and $45^{\circ} \mathrm{C}$ for 48 to $72 \mathrm{~h}$ to differentiate between mesophilic and thermophilic LAB, respectively.

${ }^{*} P<0.05 ; * * P<0.01 ; * * P<0.001$.

Molds and yeasts in the Oaxaca cheeses (Table 1) were similar to those previously found in Oaxaca cheese (Caro et al., 2013). The counts of this microbial group did not show significant changes during cheese storage. The role of molds and yeasts in cheese quality is variable. This microbiota is usually considered undesirable in soft cheeses; however, it could have a positive effect on the aroma of traditional cheeses (Jakobsen and Narvhus, 1996).

Counts of coliforms and E. coli found in the present study can be considered high (European Commission, 2005). Coliform counts were slightly higher than those found in a previous study on raw-milk Oaxaca cheese, whereas counts of $E$. coli were similar (Caro et al., 2013). Coliforms and E. coli are related to fecal contamination and are used as an index of hygiene in cheese (Ganesan et al., 2012). Moreover, coliforms are considered one of the most important spoilage bacteria in mozzarella cheese (De Angelis et al., 2008). Coliforms showed a significant decrease during the storage of Oaxaca cheese $(P<0.05)$, which could be attributed to their susceptibility to low $\mathrm{pH}$ values and to the growth and presence of LAB (De Angelis et al., 2008), with both scenarios being present in our study.

\section{Changes in Chemical Composition During Storage}

Concentrations of galactose and lactic and acetic acids, and $\mathrm{pH}$ values in Oaxaca cheese during storage are shown in Table 2. In general, pasta filata cheeses tend to contain small amounts of residual sugars due to their low curd $\mathrm{pH}$ and the sugar loss during stretching in hot water (Gernigon et al., 2009). In agreement, lactose and glucose concentrations in Oaxaca cheese were below the detection limit of the method (50 mg/100 g of cheese). Galactose showed values of approximately $300 \mathrm{mg} / 100$ $\mathrm{g}$, which were comparable to those observed in lowmoisture Mozzarella cheese (Mukherjee and Hutkins, 1994). During storage of Oaxaca cheese, the amount of galactose did not change significantly. The presence of galactose as the main sugar in pasta filata cheese has been explained by the poor ability of LAB to catabolize it, being formed by lactose hydrolysis (Mukherjee and Hutkins, 1994; Kindstedt et al., 2010). The amount of galactose has a great influence on the color of the baked cheese surface. Caro et al. (2011) observed browning on the surface of melted Oaxaca cheese after baking for 20 min at 125 to $200^{\circ} \mathrm{C}$. However, the typical use of this cheese (to prepare quesadillas or other melted-cheese dishes) implies heating at lower temperatures or for less time, which does not generate the brown color and, thus, the presence of galactose would not be relevant for the color quality of melted Oaxaca cheese.

The levels of lactic and acetic acids found in Oaxaca cheeses, as in other pasta filata cheeses, were relatively low probably because of the loss of those acids from the curd during the stretching step (Gernigon et al., 2009). The content of lactic acid in Oaxaca cheese increased during storage, reaching its highest value at d 16 , and then decreasing thereafter $(P<0.05)$. Meanwhile, the acetic acid concentration remained constant during the storage period. The increase of lactic acid during the first weeks of storage and the later decrease has also been described in mozzarella cheese (Califano and Bevilacqua, 1999; Kindstedt et al., 2010). The increase, which can be explained by residual metabolism of sugars, occurred in parallel with the increase in mesophilic lactobacilli counts (Table 1). On the other hand, the 
Table 2. Changes in selected chemical characteristics (mean $\pm \mathrm{SD}$ ) of Oaxaca cheese during storage under vacuum at $8^{\circ} \mathrm{C}$

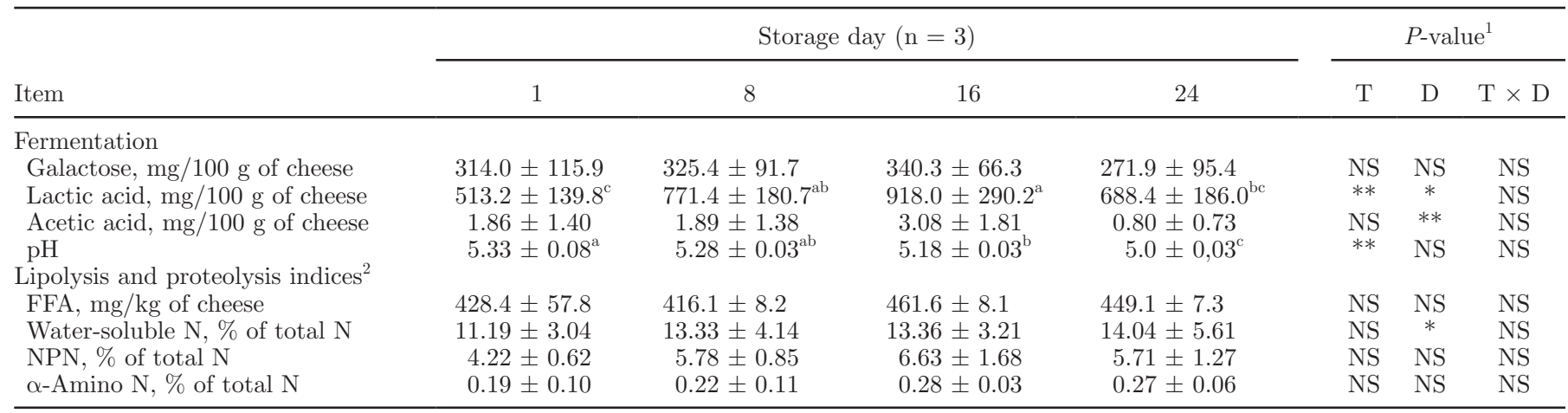

${ }^{\mathrm{a}-\mathrm{c}}$ Means in the same row with different superscripts were significantly different $(P<0.05)$.

${ }^{1} \mathrm{~T}=$ time (fixed factor); $\mathrm{D}=$ dairy plant (random factor); $\mathrm{T} \times \mathrm{D}=$ time $\times$ dairy plant interaction (random factor).

${ }^{*} P<0.05 ;{ }^{* *} P<0.01 ;{ }^{* * *} P<0.001$.

decrease has been attributed to microbial oxidation of lactate (McSweeney and Fox, 2004). The values of $\mathrm{pH}$ decreased significantly during storage. In contrast to the increase in lactic acid, the $\mathrm{pH}$ decrease continued until d 24, where $\mathrm{pH}$ values of 5.0 were reached.

Contents of FFA in Oaxaca cheese during storage are shown in Table 2. The initial values were similar to those described in cheeses with short aging periods; that is, mozzarella, Colby, or brick cheeses (Collins et al., 2003), where the effect of FFA in the flavor of cheese could be of low significance. Villanueva-Carvajal et al. (2012) reported that Oaxaca cheese does not develop aging flavors. The concentrations of FFA in Oaxaca cheese did not change during storage $(P>0.05)$. This is in agreement with Woo and Lindsay (1984), who found no change in FFA levels during storage of mozzarella cheese at 2 or $7^{\circ} \mathrm{C}$ for 4 mo. This lack of apparent lipolytic activity could be attributed, at least in part, to loss and thermal inactivation of lipases during curd stretching. Many lipases in curd are thermolabile, although some microbial lipases are not (Collins et al., 2003). Microbial lipases are intracellular enzymes that require release into the cheese matrix to exert their effect, with cell autolysis being the main cause of release (Collins et al., 2003). In this sense, the relatively short time and low temperature of storage, and the consequent maintenance of viable cell counts (reduced rate of cell autolysis) observed in Oaxaca cheese during most of the storage period (up to d 16), could help explain the constant FFA levels.

Values indicating proteolysis did not show significant changes during cheese storage (Table 2). In contrast, increases in WSN and NPN levels in low-fat mozzarella cheese during storage (up to $50 \mathrm{~d}$ ) have been repeatedly described (Yun et al., 1993; Rudan et al., 1999; Costabel et al., 2007). Residual coagulant, plasmin, or enzymes from LAB seem to be the major sources of proteolytic activity in mozzarella cheese (Yazici et al., 2010). However, the magnitude of those increases depends on storage time and stretching temperature. High stretching temperatures result in slower evolution of proteolysis in Mozzarella cheese due to thermal inactivation of coagulants and bacteria (Costabel et al., 2007; Kindstedt et al., 2010). Therefore, the relatively short storage period and a presumably high stretching temperature could explain, at least in part, the lack of time-related changes in proteolysis indices found in Oaxaca cheese.

\section{Changes in Functional Properties During Storage}

Results from the TPA of Oaxaca cheeses at different storage times are shown in Table 3 . The initial values obtained (d 1) were comparable to those observed in a previous study (Caro et al., 2014). During storage, hardness and elasticity decreased and adhesiveness increased $(P<0.05)$. As in Oaxaca cheese, hardness and elasticity in low-moisture mozzarella cheese decreases during storage, accompanied by a deterioration of the shredding property (Kindstedt, 1993). The storagerelated decrease in hardness of mozzarella cheese is mainly associated with proteolysis (Kindstedt, 1993; Tunick et al., 1995). However, in Oaxaca cheese, where proteolytic activity was not observed, texture changes should be explained by other reasons. One possible reason could be associated to the $\mathrm{pH}$ decrease (Table 2). The role of $\mathrm{pH}$ in cheese texture seems relevant, with lower $\mathrm{pH}$ resulting in lower hardness (Watkinson et al., 2001) - a decrease in $\mathrm{pH}$ affects casein structure by decreasing the net negative charge and releasing soluble (ionic) Ca. Other possible reasons would be the positive effect of storage time on the absorption of water into the protein matrix (hydration), which is accompanied by matrix swelling and reduction in protein-protein 
Table 3. Changes in functional characteristics (mean $\pm \mathrm{SD}$ ) of Oaxaca cheese during storage under vacuum at $8^{\circ} \mathrm{C}$

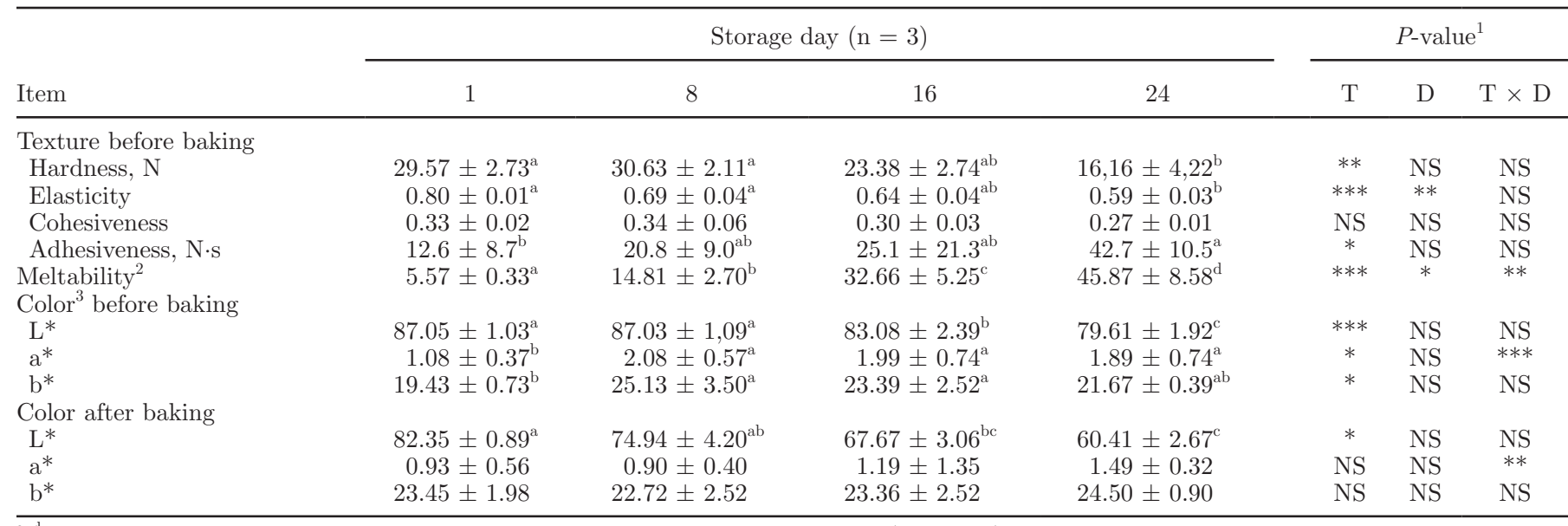

\footnotetext{
${ }^{\mathrm{a}-\mathrm{d}}$ Means in the same row with different superscripts were significantly different $(P<0.05)$.

${ }^{1} \mathrm{~T}=$ time (fixed factor); $\mathrm{D}=$ dairy plant (random factor); $\mathrm{T} \times \mathrm{D}=$ time $\times$ dairy plant interaction (random factor).

${ }^{2}$ Percentage increase in diameter of the cheese discs on heating.

${ }^{3} \mathrm{~L}^{*}=$ lightness; $\mathrm{a}^{*}=$ red-green color; $\mathrm{b}^{*}=$ yellow-blue color.

${ }^{*} P<0.05 ;{ }^{* *} P<0.01 ;{ }^{* * *} P<0.001$.
}

interaction (McMahon et al., 1999; Kindstedt et al., 2010).

Meltability of Oaxaca cheese showed a significant and steady increment during storage (Table 3). Timerelated increases in meltability during storage have been observed in low-moisture mozzarella cheese and attributed to both proteolysis and hydration of cheese protein matrix (Kindstedt, 1993; Yun et al., 1993; McMahon et al., 1999). A melting increase during storage should be considered as desirable to some extent (Kindstedt, 1993) - cheese would lose quality if it developed excessive softness and fluidness when melted. Further studies are needed to assess the preference of consumers regarding melting properties of baked Oaxaca cheese.

Changes in color characteristics of unmelted and melted Oaxaca cheeses during storage are shown in Table 3. The most noticeable change in color was the decrease in whiteness ( $\mathrm{L}^{*}$ values) for both unmelted and melted cheeses. A time-related decrease in whiteness has been also observed in stored low-moisture and low-fat Mozzarella cheeses (Rudan et al., 1999; Metzger et al., 2001; Imm et al., 2003). This effect, which has been attributed to changes in the serum phase of cheeses resulting in lower light scattering, has been considered as undesirable regarding to cheese appearance. Moreover, as observed in the present study for unmelted Oaxaca cheese, a slight increase in $\mathrm{a}^{*}$ (red-green color) values during the first weeks of storage on Mozzarella cheese has been reported (Rudan et al., 1999); however, in contrast, those authors did not find changes in $b^{*}$ values.

\section{Sensory Analysis}

Scores for cheese strength, sour, and buttery odors, and those for acidic and bitter tastes did not change during the study $(P>0.05$; data not shown). Mean values of those characteristics were $4.8 \pm 0.7,4.2 \pm 0.5$, $4.1 \pm 0.7,4.4 \pm 0.8$, and $3.9 \pm 1.0$ points, respectively, on the 9-point scale used. Creamy texture, however, showed a tendency to increase between d 8 and 16 (3.5 \pm 0.4 and $4.4 \pm 0.6$, respectively; $P<0.1$ ). The absence of significant changes in odor and taste could be related to the low fermentative, proteolytic, and lipolytic activities found in the cheeses during storage. Notwithstanding the absence of significant changes in cheese sensory characteristics, the acceptability of unmelted cheese for consumption decreased. In this sense, results showed that the proportion of the samples, within each storage day, that were found by the panelists to be unacceptable were $0 \%(\mathrm{~d} 1), 6 \%(\mathrm{~d} 8), 36 \%$ (d 16), and $81 \%(\mathrm{~d}$ 24). Deterioration of cheeses was mainly attributed to the appearance of off-odors and excessive softness.

\section{Differences in Cheese Characteristics Between Dairy Plants}

Proximate composition of the Oaxaca cheeses from each of the dairy plants sampled in this study is shown in Table 4. The values found are within the ranges reported for this cheese in previous studies (De OcaFlores et al., 2009; Caro et al., 2014). We found some differences between dairy plants $(P<0.05)$. Cheese 
Table 4. Proximate composition of the Oaxaca cheeses and other quality characteristics (mean $\pm \mathrm{SD}$; data from the 4 sampling days included) showing significant differences $(P<0.05)$ among dairy plants

\begin{tabular}{|c|c|c|c|}
\hline \multirow[b]{2}{*}{ Item } & \multicolumn{3}{|c|}{ Dairy plant } \\
\hline & 1 & 2 & 3 \\
\hline \multicolumn{4}{|l|}{ Proximate composition $(\mathrm{n}=2)$} \\
\hline TS, $\%$ & $52.9 \pm 2.5^{\mathrm{ab}}$ & $49.4 \pm 0.1^{\mathrm{b}}$ & $51.1 \pm 0.4^{\mathrm{a}}$ \\
\hline Ash, \% & $3.8 \pm 0.1^{\mathrm{a}}$ & $3.0 \pm 0.2^{\mathrm{b}}$ & $3.0 \pm 0.2^{\mathrm{b}}$ \\
\hline $\mathrm{NaCl}, \%$ & $1.8 \pm 0.1^{\mathrm{a}}$ & $1.0 \pm 0.4^{\mathrm{ab}}$ & $0.8 \pm 0.1^{\mathrm{b}}$ \\
\hline Salt-in-moisture, \% & $3.8 \pm 0.1^{\mathrm{a}}$ & $2.0 \pm 0.7^{\mathrm{ab}}$ & $1.5 \pm 0.1^{\mathrm{b}}$ \\
\hline \multicolumn{4}{|l|}{ Microbiology $(\mathrm{n}=8)$} \\
\hline Aerobic mesophilic bacteria, $\log _{10} \mathrm{cfu} / \mathrm{g}$ & $7.53 \pm 0.33^{\mathrm{c}}$ & $7.69 \pm 0.41^{\mathrm{b}}$ & $7.88 \pm 0.51^{\mathrm{a}}$ \\
\hline Lactobacilli $\left(45^{\circ} \mathrm{C}\right), \log _{10} \mathrm{cfu} / \mathrm{g}$ & $6.35 \pm 0.37^{\mathrm{c}}$ & $7.06 \pm 0.40^{\mathrm{b}}$ & $7.47 \pm 0.39^{\mathrm{a}}$ \\
\hline \multicolumn{4}{|l|}{ Chemical composition $(n=8)$} \\
\hline Lactic acid, mg/100 g & $485.2 \pm 158.0^{\mathrm{c}}$ & $623.4 \pm 223.6^{\mathrm{b}}$ & $759.8 \pm 185.5^{\mathrm{a}}$ \\
\hline Acetic acid, mg/100 g & $0.55 \pm 0.61^{\mathrm{b}}$ & $1.97 \pm 1.21^{\mathrm{ab}}$ & $3.20 \pm 2.32^{\mathrm{a}}$ \\
\hline Water-soluble $\mathrm{N}, \%$ of total $\mathrm{N}$ & $16.8 \pm 4.02^{\mathrm{a}}$ & $11.45 \pm 4.57^{\mathrm{b}}$ & $10.72 \pm 2.49^{\mathrm{b}}$ \\
\hline \multicolumn{4}{|l|}{ Functionality $(\mathrm{n}=8)$} \\
\hline Elasticity & $0.67 \pm 0.09^{\mathrm{b}}$ & $0.74 \pm 0.09^{\mathrm{a}}$ & $0.69 \pm 0.08^{\mathrm{b}}$ \\
\hline Meltability, \% increase in diameter & $20.5 \pm 13.7^{\mathrm{b}}$ & $28.9 \pm 20.0^{\mathrm{a}}$ & $25.2 \pm 17.9^{\mathrm{a}}$ \\
\hline \multicolumn{4}{|l|}{ Sensorial $(\mathrm{n}=8)$} \\
\hline Bitter taste, 9-point scale & $4.80 \pm 0.88^{\mathrm{a}}$ & $3.53 \pm 0.69^{b}$ & $3.37 \pm 0.78^{\mathrm{b}}$ \\
\hline Unacceptability $^{1}$ (at storage d 8-16-24) & $11-55-100$ & 5-33-83 & $0-22-61$ \\
\hline
\end{tabular}

from plant 3 showed lower $\mathrm{NaCl}$ content and salt-tomoisture ratio than cheese from plant 1 , and higher total solids content than cheese from plant 2 .

Differences in cheese characteristics between plants were also detected for aerobic mesophilic bacteria and lactobacilli $\left(45^{\circ} \mathrm{C}\right)$ counts, lactic and acetic acids and WSN contents, elasticity and meltability values, and bitter taste by the mixed-model ANOVA $(P<0.05$; Tables 1 to 3 ). The mean values found for those characteristics in the cheeses from each plant, considering together the data from all sampling days, are also shown in Table 4. The most remarkable findings were that cheeses from dairy plant 1 showed the lowest counts of aerobic mesophilic bacteria and lactobacilli, lactic and acetic acid contents, and meltability values, and the highest WSN content and bitter taste score. Furthermore, counts of aerobic mesophilic bacteria and lactobacilli, and lactic acid contents were lower in cheeses from plant 2 than in those from plant 3. Moreover, the sensorial rejection of cheeses at and beyond $8 \mathrm{~d}$ of storage appeared to be the highest in cheeses from plant 1 , whereas cheeses from plant 3 showed the lowest rejection percentages.

A significant interaction between dairy plant $\times$ storage time was detected. Thus, the pattern of changes in microbial counts, meltability, and $\mathrm{a}^{*}$ during cheese storage differed between dairy plants $(P<0.05$; Tables $1,2$, and 3$)$. Cheese from plant 1 showed lower total mesophilic bacteria counts and a lesser increase in those counts from d 8 to 16 than the cheeses from the other plants, the cheeses from plant 2 being intermediate (Figure 1A). Moreover, differences in cheese meltability between plants were detected after $8 \mathrm{~d}$ of storage, when cheese from plant 1 showed lower meltability than those from the other 2 plants.

The above-mentioned differences between plants could be explained both by variation in the milk or cheese proximal composition and in the cheese-making process. Probably the most relevant difference in proximate composition of cheeses among dairy plants was salt:moisture ratio, which ranged from 3.8 (plant 1) to 1.5 (plant 3). Variation in salt levels in pasta filata cheese can affect their quality: increasing salt contents can result in a reduction in LAB growth, lactic acid production, and proteolytic activity and an increase in casein hydration, protein solubility, and free oil formation (Everett et al., 2004; Guinee and Fox, 2004). Our results show that increasing salt content or salt:moisture ratio in Oaxaca cheese might have been responsible, at least in part, for decreasing counts of aerobic mesophilic bacteria and lactobacilli, decreasing contents of lactic and acetic acids, and reduced meltability and shelf life (acceptability of stored cheeses), as well as increasing WSN.

\section{CONCLUSIONS}

The main changes of Oaxaca cheese during refrigerated vacuum storage were decreases in $\mathrm{pH}$ value, hardness, and $\mathrm{L}^{*}$, and an increase in meltability. These 

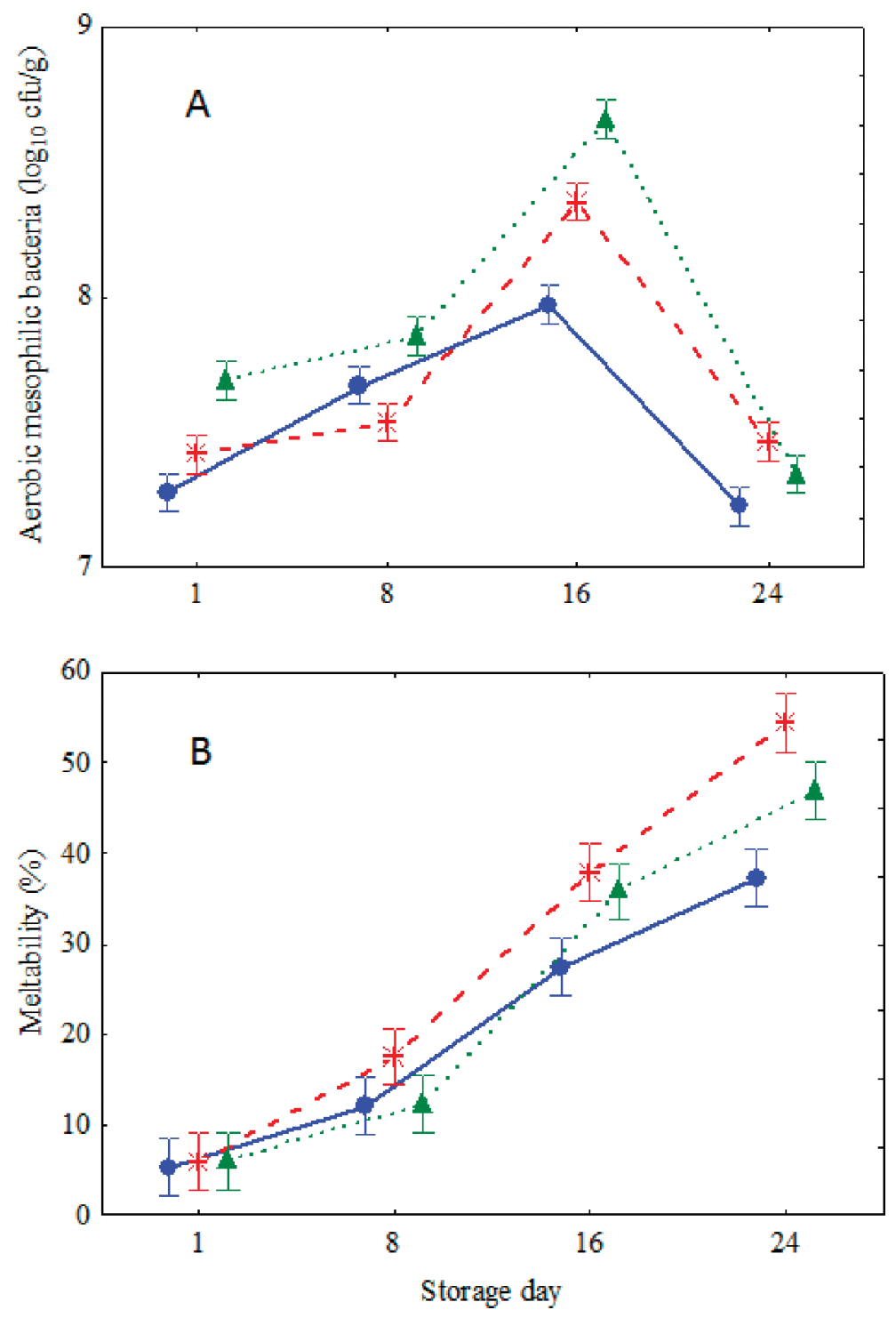

Figure 1. Changes in (A) aerobic mesophilic bacteria counts and (B) meltability values during storage of cheeses from different dairy plants $(1=\mathbf{\bullet} ; 2=* ; 3=\mathbf{\Delta})$; error bars are $95 \%$ CI. Color version available online.

changes might be attributed to moderate residual sugar fermentation and to changes in the cheese protein matrix (hydration, loss of soluble calcium). Furthermore, storage of Oaxaca cheese for more than 1 wk resulted in a gradual loss of quality. On the other hand, neither proteolytic nor lipolytic activities were evident during storage of Oaxaca cheese. Further research on the effects of milk pasteurization, kneading conditions (time and temperature), salt and moisture contents in cheese, and storage temperature on the quality of Oaxaca cheese, especially with respect to functionality and shelf life, are suggested to complete the present research.

\section{REFERENCES}

Aguilar-Uscanga, B., M. Montero-Lagunes, J. De la Cruz, J. R. SolísPacheco, and H. S. García. 2006. Using fermented cheese whey to reduce acidification time of Oaxaca cheese. Agrociencia 40:569575.

Alba, L. A., C. de Staff, R. L. Richter, and C. V. Dill. 1990. Mexican Asadero cheese: A survey of its composition. J. Dairy Sci. 73(Suppl. 1):269.

AOAC International. 1999. Official Methods of Analysis. Vol. II. 16th ed. AOAC International, Gaithersburg, MD.

Bligh, E. G., and W. J. Dyer. 1959. A rapid method of total lipid extraction and purification. Can. J. Biochem. Physiol. 37:911-917.

Califano, A. N., and A. E. Bevilacqua. 1999. Freezing low moisture Mozzarella cheese: Changes in organic acid content. Food Chem. 64:193-198. 
Caro, I., J. Mateo, M. H. Sandoval, S. Soto, M. R. García-Armesto, and J. M. Castro. 2013. Characterization of Oaxaca raw milk cheese microbiota with particular interest in Lactobacillus strains. J. Dairy Sci. 96:3461-3470.

Caro, I., S. Soto, M. J. Franco, M. Meza-Nieto, R. H. Alfaro-Rodríguez, and J. Mateo. 2011. Composition, yield and functionality of reduced-fat Oaxaca cheese: Effects of using skim milk or a dry milk protein concentrate. J. Dairy Sci. 94:580-588.

Caro, I., S. Soto, L. Fuentes, N. Gutiérrez-Méndez, B. García-Islas, K. E. Monroy-Galloso, and J. Mateo. 2014. Compositional, functional and sensory characteristics of selected Mexican cheeses. Food Nutr. Sci 5:366-375.

Colín-Cruz, M. A., O. Dublán-García, A. Espinoza-Ortega, and O. Dominguez-Lopez. 2012. The effect of varying fat content on the microstructure of Oaxaca cheese, a typical pasta filata cheese. Int. J. Dairy Technol. 65:71-80.

Collins, Y. F., P. L. M. McSweeney, and M. G. Wilkinson. 2003. Lipolysis and free fatty acid catabolism in cheese: A review of current knowledge. Int. Dairy J. 13:841-866.

European Commission. 2005. Commission Regulation (EC) No 2073/2005 of 15 November 2005 on microbiological criteria for foodstuffs. Off. J. L338:1-26.

Conte, A., C. Scrocco, M. Sinigaglia, and M. A. Del Nobile. 2007. Innovative active packaging systems to prolong the shelf life of Mozzarella cheese. J. Dairy Sci. 90:2126-2131.

Costabel, L., M. S. Pauletti, and E. Hynes. 2007. Proteolysis in Mozzarella cheeses manufactured by different industrial processes. J. Dairy Sci. 90:2103-2112.

De Angelis, M., S. de Candia, M. P. Calasso, M. Faccia, T. P. Guinee, M. C. Simonetti, and M. Gobbetti. 2008. Selection and use of autochthonous multiple strain cultures for the manufacture of high moisture traditional Mozzarella cheese. Int. J. Food Microbiol. 125:123-132.

De Oca-Flores, E. M., O. A. Castelán-Ortega, J. E. Estrada-Flores, and A. Espinoza-Ortega. 2009. Oaxaca cheese: Manufacture process and physicochemical characteristics. Int. J. Dairy Technol. 62:535-540.

Domínguez-López, A., A. Villanueva-Carvajal, C. Arriaga-Jordán, and A. Espinoza-Ortega. 2011. Artisan-made and traditional foods: The Oaxaca fresh cheese as study case in central Mexico. Estud. Soc. 19:165-193.

Everett, D. W., M. K. Rowney, M. W. Hickey, and P. Roupas. 2004. Salt-induced structural changes in Mozzarella cheese and the impact upon free oil formation in ripening cheese. Lait 84:539-549.

Foegeding, E. A., and M. A. Drake. 2007. Invited Review: Sensory and mechanical properties of cheese texture. J. Dairy Sci. 90:16111624.

Fox, F. P., P. L. M. Mc Sweeney, T. M. Cogan, and T. P. Guinee. 2000. Fundamentals of Cheese Science. Aspen Publishing, Gaithersburg, MD.

Ganesan, B., D. A. Irish, C. Brothersen, and D. J. McMahon. 2012. Evaluation of microbial survival post-incidence on fresh Mozzarella cheese. J. Dairy Sci. 95:6891-6896.

García-Regueiro, J. A., J. Gibert, and I. Díaz. 1994. Determination of neutral lipids from subcutaneous fat of cured ham by capillary gas chromatography and liquid chromatography. J. Chromatogr. A $667: 225-233$.

Gernigon, G., M. Piot, E. Beaucher, R. Jeantet, and P. Schuck. 2009. Physicochemical characterization of Mozzarella cheese wheys and stretchwaters in comparison with several other sweet wheys. J. Dairy Sci. 92:5371-5377.

González de Llano, D., A. Rodríguez, and P. Cuesta. 1996. Effect of lactic starter cultures on the organic acid composition of milk and cheese during ripening-analysis by HPLC. J. Appl. Bacteriol. 80:570-576.

Guinee, T. P., and F. P. Fox. 2004. Salt in cheese: Physical, chemical and biological aspects. Pages 207-261 in Cheese: Chemistry, Physics and Microbiology. General Aspects, Vol. 1. 3rd ed. P. F. Fox, P. L. H. McSweeney, T. M. Cogan, T. P. Guinee, ed. Elsevier Academic Press, Amsterdam, the Netherlands.
Guinee, T. P., D. Harrington, M. O. Corcoran, E. O. Mulholland, and C. Mullins. 2000. The compositional and functional properties of commercial mozzarella, cheddar and analogue pizza cheeses. Int. J. Dairy Technol. 53:51-56.

IDF (International Dairy Federation). 1986. Fat, cheese and processed cheese: Determination of fat content, Schmid-Bondzynskiratzlaff method. Standard 5B. IDF, Brussels, Belgium.

IDF (International Dairy Federation). 1995. Milk and milk productsGuidance on methods of sampling. Standard 50C. IDF, Brussels, Belgium.

IDF (International Dairy Federation). 1996. Preparation of samples and dilutions for microbiological examination. Standard 122C. IDF, Brussels, Belgium.

Imm, J. Y., E. J. Ong, K. S. Han, S. Oh, Y. M. Park, and S. H. Kim. 2003. Funtionality and physico-chemical characteristics of bovine and caprine Mozzarella cheeses during refrigerated storage. J. Dairy Sci. 86:2790-2798.

Jakobsen, M., and J. Narvhus. 1996. Yeasts and their possible beneficial and negative effects on the quality of dairy products. Int. Dairy J. 6:755-768.

Kindstedt, P. S. 1993. Effect of manufacturing factors, composition, and proteolysis on the functional characteristics of mozzarella cheese. Crit. Rev. Food Sci. Nutr. 33:167-187.

Kindstedt, P. S., A. J. Hillier, and J. J. Mayes. 2010. Technology, biochemistry and functionality of pasta filata/pizza cheese. Pages 330-359 in Technology of Cheesemaking. B. A. Law, and A. Y. Tamine, ed. Wiley-Blackwell, Oxford, UK.

McMahon, D. J., R. L. Fife, and C. J. Oberg. 1999. Water partitioning in Mozzarella cheese and its relationship to cheese meltability. J. Dairy Sci. 82:1361-1369.

McSweeney, P. L. H., and P. F. Fox. 2004. Metabolism of residual lactose and of lactate and citrate. Pages 361-372 in Cheese: Chemistry, Physics and Microbiology. General Aspects, Vol. 1. General Aspects. 3rd ed. P. F. Fox, P. L. H. McSweeney, T. M. Cogan, and T. P. Guinee, ed. Elsevier Academic Press, Amsterdam, the Netherlands.

Metzger, L. E., D. M. Barbano, P. S. Kindstedt, and M. R. Guo. 2001. Effect of milk preacidification on low fat Mozzarella cheese: II. Chemical and functional properties during storage. J. Dairy Sci. 84:1348-1356.

Moller, K. K., F. P. Rattray, and Y. Ardö. 2013. Application of selected lactic acid bacteria and coagulant for improving the quality of low-salt Cheddar cheese: Chemical, microbiological and rheological evaluation. Int. Dairy J. 33:163-174.

Morales-Celaya, M. F., C. Lobato-Callerosa, J. Álvarez-Ramírez, and E. J. Vernon-Carter. 2012. Effect of milk pasteurization and acidification method on the chemical composition and microstructure of a Mexican pasta filata cheese. Lebenson. Wiss. Technol. 45:132-141.

Mukherjee, K. K., and R. W. Hutkins. 1994. Isolation of galactosefermenting thermophilic cultures and their use in the manufacture of low browning Mozzarella cheese. J. Dairy Sci. 77:2839-2849.

Osorio, M. T., J. M. Zumalacárregui, A. C. Figueira, and J. Mateo. 2007. Physicochemical properties of perirenal and omental fat from suckling lamb carcasses evaluated according to the type of milk source. Small Rumin. Res. 72:111-118.

Poste, L. M., D. A. Mackie, G. Butler, and E. Larmond. 1991. Laboratory Methods for Sensory Analysis of Food. Research Branch. Agriculture Canada Publication 1864/E. Canada Communication Group-Publishing Centre, Ottawa, Canada.

Retiveau, A., D. H. Chambers, and E. Esteve. 2005. Developing a lexicon for the flavor description of French cheeses. Food Qual. Prefer. 16:517-527.

Rosen, H. 1957. A modified ninhydrin colorimetric analysis for amino acids. Arch. Biochem. Biophys. 67:10-15.

Rudan, M. A., D. M. Barbano, R. G. Ming, and P. S. Kindstedt. 1999. Effects of the modification of fat particle size by homogenization on composition, proteolysis, functionality, and appearance of reduced fat Mozzarella cheese. J. Dairy Sci. 81:2065-2076. 
Saxer, S., S. M. Schewenninger, and C. Lacroix. 2013. Characterization of the microflora of industrial Mexican cheeses produced without added chemical preservatives. Lebenson. Wiss. Technol. $53: 314-320$.

Tunick, M. H., E. L. Malin, P. W. Smith, and V. H. Holsinger. 1995. Effect of skim milk homogenization on proteolysis and rheology of Mozzarella cheese. Int. Dairy J. 5:483-491.

Van Vliet, T. 1991. Terminology to be used in cheese rheology. Pages 5-15 in Rheological and Fracture Properties of Cheese. Bull. No. 268. International Dairy Federation, Brussels, Belgium.

Villanueva-Carvajal, A., M. Esteban-Chávez, A. Espinoza-Ortega, C. M. Arriaga-Jordán, and A. Domínguez-Lopez. 2012. Oaxaca cheese: Flavour, texture and their interaction in a Mexican traditional pasta filata type cheese. CyTA J. Food 10:63-70.

Watkinson, P., C. Coker, R. Crawford, C. Dodds, K. Johnston, A. McKenna, and N. White. 2001. Effect of cheese $\mathrm{pH}$ and ripening time on model cheese textural properties and proteolysis. Int Dairy J. 11:455-464.

Woo, A. H., and R. C. Lindsay. 1984. Concentrations of major free fatty acids and flavor development in Italian cheese varieties. J. Dairy Sci. 67:960-968.

Yazici, F., M. Dervisoglu, A. Akgun, and O. Aydemir. 2010. Effect of whey $\mathrm{pH}$ at drainage on physicochemical, biochemical, microbiological and sensory properties of Mozzarella cheese made from bufalo milk during refrigerated storage. J. Dairy Sci. 93:5010-5019.

Yun, J. J., L. J. Kiely, D. M. Barbano, and P. S. Kindstedt. 1993. Mozzarella cheese: Impact of cooking temperature on chemical composition, proteolysis and functional properties. J. Dairy Sci. 76:3664-3673 